\title{
Death of Procedural Safeguards: Prior Restraint, Due Process and the Elusive First Amendment Value of Content Neutrality
}

\author{
Edward L. Carter \\ ed_carter@byu.edu \\ Brad Clark
}

Follow this and additional works at: https://scholarsarchive.byu.edu/facpub

Part of the Communication Commons

\section{Original Publication Citation}

Carter, Edward L., Clark, Brad. "Death of Procedural Safeguards: Prior Restraint, Due Process and the Elusive First Amendment Value of Content Neutrality." Communication Law and Policy (26).

\section{BYU ScholarsArchive Citation}

Carter, Edward L. and Clark, Brad, "Death of Procedural Safeguards: Prior Restraint, Due Process and the Elusive First Amendment Value of Content Neutrality" (2006). Faculty Publications. 960.

https://scholarsarchive.byu.edu/facpub/960 
11 Comm. L. \& PoL'Y 225-254 (2006)

Copyright () 2006, Lawrence Erlbaum Associates, Inc.

\section{DEATH OF PROCEDURAL SAFEGUARDS: PRIOR RESTRAINT, DUE PROCESS AND THE ELUSIVE FIRST AMENDMENT VALUE OF CONTENT NEUTRALITY}

\section{EDWARD L. CARTER* \\ BRAD CLARK**}

In recent years, federal courts eroded the procedural safeguards required for prior restraint licensing schemes established in Freedman v. Maryland. The Supreme Court of the United States stated that the dangers of prior restraint were accounted for by content neutrality. But a close examination of federal courts of appeals opinions since 2002 reveals that erosion of procedural safeguards may threaten speech interests. First, procedural safeguards have not been required, in some cases, even for content-based prior restraints.

Second, courts of appeals have held that, in the context of content-neutral prior restraints, the First Amendment no longer requires a time limit on the initial

administrative censor's decision about whether to allow speech. This limit was key to ensuring due process, and its absence allows government to stifle speech it disfavors even while maintaining the appearance of content neutrality.

Since 1931, when the Supreme Court of the United States struck down a government effort to prevent publication of a "scandalous" newspaper in Near $v$. Minnesota, ${ }^{1}$ few sentiments have been evoked

\footnotetext{
*Assistant Professor, Department of Communications, Brigham Young University.

**Master's student, Department of Communications, Brigham Young University.
}

1283 U.S. 697 (1931). 
as often as the one that came to embody the doctrine of prior restraint: "Any system of prior restraint ... comes to this Court bearing a heavy presumption against its constitutional validity." 2 While this principle has received much lip service, it has not prevented federal and state governments from engaging in prior restraint of substantial amounts of speech. A close examination of recent federal court opinions reveals that, at least with respect to so-called contentneutral prior restraints in the context of licensing, the presumption has been somewhat reversed: Many prior restraints are now presumed constitutional and may be immediately effected unless and until the speech proponent goes to court and carries the burden to show the speech should be protected.

This study analyzes recent prior restraint challenges in the Supreme Court and United States Circuit Courts of Appeal in order to draw conclusions about the theoretical and practical validity of content neutrality as a primary value of the prior restraint doctrine and, by extension, free speech jurisprudence generally. Since 2002, federal courts have chipped away at the procedural safeguards that were required for licensing schemes to pass constitutional muster after Freedman v. Maryland. ${ }^{3}$ The procedural safeguards advanced in that case largely have been eviscerated in light of federal courts' conclusions that the dangers of prior restraint are not present when licensing schemes are content neutral.

Analysis of these opinions, however, shows that speech interests are being threatened and sometimes impaired in at least two ways by this erosion of procedural safeguards in favor of content neutrality. First, courts sometimes have not required procedural safeguards even when prior restraints were content-based. Second, federal courts of appeals uniformly have interpreted two Supreme Court opinions since 2002 to mean that the First Amendment no longer requires a time limit on the initial administrative decision about whether to allow speech in a content-neutral prior restraint licensing scheme. Elimination of the time-limit requirement, which constituted the essence of Freedman's concern for ensuring due process in case of threatened speech deprivation, may allow government to suppress speech it disfavors even while maintaining the appearance of content neutrality.

The death of procedural safeguards would in large part mark the end of the era of "First Amendment due process," as Professor Henry

\footnotetext{
${ }^{2}$ Southeastern Promotions, Ltd. v. Conrad, 420 U.S. 546, 558 (1975) (internal quotation and citation omitted).

3380 U.S. 51 (1965).
} 
Monaghan called the Court's jurisprudence after Freedman. ${ }^{4}$ In a seminal article identifying the rise of procedural safeguards as a means of protecting speech due process, Professor Monaghan quoted Justice Felix Frankfurter: "The history of American freedom is, in no small measure, the history of procedure."5 Professor Monaghan and the Supreme Court on which he commented advanced the idea that procedural safeguards such as those expounded in Freedman "'assume[d] an importance fully as great as the validity of the substantive rule of law to be applied." 6 Professor Monaghan noted that the notion of speech due process, which arose not from the Fifth or Fourteenth amendments but rather directly from the First Amendment itself, first took shape in obscenity cases; nevertheless, he argued, the Court's rationale that procedures must be in place in order to "show "the necessary sensitivity to freedom of expression"" 7 applied just as well to attempted prior restraints of other speech, including political speech. Using the same rationale, the contemporary erosion of procedural safeguards for content-neutral prior restraints of sexually oriented speech may also erode due process for other types of speech.

In this article, we first review the longstanding constitutional aversion to prior restraints and content-based regulation of speech. We then track the rise and fall of procedural safeguards as protections against improper prior restraints of speech. We note that, in two opinions since 2002, the Supreme Court has not required procedural safeguards for content-neutral prior restraint licensing regimes. We discuss the merits of the Court's replacement of procedural safeguards with the ideal of content neutrality. We also analyze seventeen courts of appeals opinions since 2002 applying the Court's new approach and discuss the effect of those opinions on speech interests. We conclude that death of procedural safeguards in the content-neutral regulation context poses the threat of undermining protections against improper government regulation of speech. The reality of this threat is demonstrated by the appeals courts' opinions, some of which did not require procedural safeguards even for content-based regulation or concluded that administrative censors no longer face a reasonable time deadline in making a decision

\footnotetext{
${ }^{4}$ See Henry P. Monaghan, First Amendment "Due Process," 83 HARV. L. REv. 518 (1970).

5Id. at 518 (quoting Malinski v. New York, 324 U.S. 401, 414 (1945) (Frankfurter, J., separate opinion)).

${ }^{6} I d$. (quoting Speiser v. Randall, 357 U.S. 513, 520 (1958)).

${ }^{7} I d$. at 519 (quoting Freedman v. Maryland, 380 U.S. 51, 58 (1965)).
} 
about whether to allow speech in a content-neutral permit scheme. Ultimately, the direction of recent jurisprudence could undermine substantive speech protections and longstanding constitutional guarantees of due process in the prior restraint context.

\section{The First AMENDMENT}

The First Amendment to the Constitution of the United States provides that "Congress shall make no law respecting an establishment of religion, or prohibiting the free exercise thereof; or abridging the freedom of speech, or of the press." 8 The Supreme Court has "interpreted the First Amendment as providing greater protection from prior restraints than from subsequent punishments."9 There is a deep and longstanding aversion in First Amendment jurisprudence to prior restraints, in part because of the sixteenth and seventeenth century English roots of prior restraint in licensing schemes. ${ }^{10}$ In alluding to this aversion, the Supreme Court concluded that "a free society prefers to punish the few who abuse rights of speech after they break the law than to throttle them and all others beforehand."11

With respect to First Amendment jurisprudence generally, scholars have identified two regulatory tracks. ${ }^{12}$ On the first track, government regulation targets the message of speech directly because of concerns with its communicative impact. 13 Track one speech regulations ${ }^{14}$ include prohibitions against incitement to imminent unlawful conduct, 15 fighting words and true threats, ${ }^{16}$ obscenity 17 and some libels. 18 Track two regulations, meanwhile, do not primarily target the communicative impact of speech, although regulations in

${ }^{8}$ U.S. CONST. amend. I.

${ }^{9}$ Alexander v. United States, 509 U.S. 544, 554 (1993). See also Southeastern Promotions Ltd. v. Conrad, 420 U.S. 546, 558-59 (1975) ("The presumption against prior restraints is heavier-and the degree of protection broader - than that against limits on expression imposed by criminal penalties.").

${ }^{10} I d$.

${ }^{11}$ Southeastern Promotions, 420 U.S. at 559.

${ }^{12}$ See, e.g., LAUREnCe H. TRIBE, American Constitutional LaW $\S 12-2$, at 791 (1988); Larry A. Alexander, Trouble on Track Two: Incidental Regulations of Speech and Free Speech Theory, 44 HASTINGs L.J. 921 (1993).

${ }^{13}$ See Alexander, supra note 12, at 921.

${ }^{14}$ For a comprehensive list, see id. at 922 n.4.

${ }_{15}^{15}$ ee Brandenburg v. Ohio, 395 U.S. 444 (1969).

${ }^{16}$ See Virginia v. Black, 538 U.S. 343 (2003); Chaplinsky v. New Hampshire, 315 U.S. 568 (1942).

${ }^{17}$ See Miller v. California, 413 U.S. 15 (1973).

${ }^{18}$ See New York Times Co. v. Sullivan, 376 U.S. 254 (1964). 
this area may impose incidental burdens on speech. ${ }^{19}$ In this second track, for example, government may place restrictions on the time, place or manner of speech in a public forum, ${ }^{20}$ or government may regulate conduct that has an expressive component. ${ }^{21}$ One scholar concluded that Supreme Court cases in track one, where the government engages in content-based regulation, are generally speech-protective; on the other hand, the Court's cases in track two, where the regulation is content neutral, are not generally speech-protective. ${ }^{22}$

Scholars have concluded that contemporary prior restraint jurisprudence fails to adequately protect the right of the press to publish what it wishes. ${ }^{23}$ Other scholars have condemned prior restraints that are imposed without the benefit of judicial review. ${ }^{24}$ While there have been proposals to improve the prior restraint doctrine, 25 the scholarship has not, for the most part, focused attention on the demise of the Freedman procedural safeguards 26 and recent efforts by federal courts, in light of that demise, to apply content neutrality in place of the safeguards.

${ }^{19}$ See TRIBE, supra note 12, at 792; Alexander, supra note 12, at 923.

${ }^{20}$ See Ward v. Rock Against Racism, 491 U.S. 781 (1981).

${ }^{21}$ See United States v. O'Brien, 391 U.S. 367 (1968).

${ }^{22}$ See Alexander, supra note 12 , at 925.

${ }^{23}$ See, e.g., Jeffery A. Smith, Prior Restraint: Original Intentions and Modern Interpretations, 28 WM. \& MARY L. REV. 439, 470-72 (1987).

${ }^{24}$ See, e.g., Martin H. Redish, The Proper Role of the Prior Restraint Doctrine in First Amendment Theory, 70 VA. L. REv. 53, 99-100 (1984).

${ }^{25}$ See id. at 57 (proposing that all prior restraints imposed before a judicial hearing are unconstitutional). See also, Richard Favata, Note, Filling the Void in First Amendment Jurisprudence: Is There a Solution for Replacing the Impotent System of Prior Restraints?, 72 FORDHAM L. REV. 169 (2003) (proposing that clearly invalid prior restraints be ignored under a collateral bar rule); Smith, supra note 23, at 44750 (favoring the absolutist view that the government may not impose any prior restraints on the news media).

26Some recent student-written legal scholarship has begun to discuss the impact on the Freedman safeguards of two Supreme Court opinions since 2002-Thomas $v$. Chicago Park District, 534 U.S. 316 (2002) and City of Littleton, Colorado v. Z.J. Gifts D-4, 541 U.S. 774 (2004). For example, one note called for preservation of the Freedman safeguards and even advocated that they be applied regardless of whether the regulation in question is content-based or content-neutral. See Kathryn F. Whittington, Note, The Prior Restraint Doctrine and the Freedman Protections: Navigating a Gigantic Labyrinth, 52 FLA. L. REV. 809 (2000). Similarly, a comment addressed Thomas, which held that the safeguards were not required for contentneutral prior restraint schemes. The author raised the issue of the difficulty for courts to distinguish between content-based prior restraint schemes and contentneutral regimes. See Robert H. Whorf, The Dangerous Intersection at Prior Restraint and "Time, Place, Manner": A Comment on Thomas v. Chicago Park District, 3 BARRY L. REV. 1 (2002). 


\section{Rise AND FALL OF SAFEgUARDS IN SUPREME COURT JURISPRUDENCE}

In 1965, the Supreme Court in Freedman v. Maryland 27 articulated a series of procedural safeguards that must be in place in order for a system of prior restraint to pass muster under the First Amendment. The Court's articulation of the safeguards came in response to a Maryland statute that required all motion pictures to be approved by the State Board of Censors before they could be exhibited.28 Under the law, the board was to approve films that were "moral and proper" and was to "disapprove such as are obscene, or such as tend, in the judgment of the Board, to debase or corrupt morals or incite to crimes." 29

The Supreme Court held that the Maryland censorship law unconstitutionally abridged the freedom of speech because it failed to provide three procedural safeguards. First, the Court held that the regulatory scheme must place the burden of proving that the film was not protected expression on the state censor rather than on the film proponent. ${ }^{30}$ Second, the censorship program could not have the effect of rendering the censor's determination final; 31 rather, any temporary restraint pending a judicial determination must preserve the status quo. Third, the regulatory scheme "must also assure a prompt final judicial decision, to minimize the deterrent effect of an interim and possibly erroneous denial of a license." 32

The Supreme Court emphasized that the procedural safeguards were necessary even though the speech proponent would have the substantive protections of First Amendment law. First, "Because the censor's business is to censor, there inheres the danger that he may well be less responsive than a court-part of an independent branch of government- to the constitutionally protected interests in free expression." 33 The censor's decision might in practice be final if the review process involves delay or is otherwise onerous. Second, the

\footnotetext{
27380 U.S. 51 (1965).

${ }^{28}$ The Maryland law stated in part: "It shall be unlawful to sell, lease, lend, exhibit or use any motion picture film or view in the State of Maryland unless the said film or view has been submitted by the exchange, owner or lessee of the film or view and duly approved and licensed by the Maryland State Board of Censors, hereinafter in this article called the Board." MD. CODE ANN. art. 66A, §2 (1957), quoted in Freedman, 380 U.S. at 53 (1965).

${ }^{29}$ MD. CodE ANN. art. 66A, §6(a) (1957), quoted in Freedman, 380 U.S. at 53.

${ }^{30}$ Freedman, 380 U.S. at 58.

${ }^{31} I d$. at $58-59$.

${ }^{32} \mathrm{Id}$. at 59 .

${ }^{33} \mathrm{Id}$. at $57-58$.
} 
Court concluded, not every speech proponent who faces censorship will have the resources to initiate litigation. 34 In that case, some speech will be lost and the overall quantity of speech will be less than if the procedural safeguards had been in place.

The procedural safeguards expounded in Freedman were not confined to the context of film censorship. The Court subsequently applied them to the regulatory schemes that resulted in seizure of photographs by U.S. customs agents, ${ }^{35}$ seizure of mail by U.S. postal officials, 36 and rejection of an application to stage a musical in a municipal theater. ${ }^{37}$ The procedural safeguards also were applied to a nuisance statute, 38 a professional licensing scheme for charity fund raising, 39 and a licensing system for adult businesses. ${ }^{40}$ Some equivocal language in a 1990 Supreme Court opinion led to a split in the federal circuit courts of appeal about whether a judicial resolution or mere access to judicial proceedings was required. ${ }^{41}$ Ultimately, the Court quashed the notion that it had ever deviated from the judicial resolution requirement, thus apparently resolving the split in favor of vigorous protection of speech. 42

In two recent decisions, however, the Court appears to have significantly limited the application of Freedman's procedural safeguards. First, in Thomas v. Chicago Park District ${ }^{43}$ in 2002, the Court held for the first time that the Freedman procedural safeguards did not apply to a content-neutral permit scheme regulating the time, place

${ }^{34} \mathrm{Id}$. at 59 .

35United States v. Thirty-Seven Photographs, 402 U.S. 363 (1971).

${ }^{36}$ Blount v. Rizzi, 400 U.S. 410 (1971).

${ }^{37}$ Southeastern Promotions, Ltd. v. Conrad, 420 U.S. 546 (1975).

38 Vance v. Universal Amusement Co., 445 U.S. 308 (1980).

${ }^{39}$ Riley v. Nat'l Fed'n of Blind of N.C., Inc., 487 U.S. 781 (1988).

${ }^{40}$ FW/PBS, Inc. v. City of Dallas, 493 U.S. 215 (1990).

41Justice Sandra Day O'Connor wrote the majority opinion in FW/PBS, Inc. $v$. City of Dallas, id. but a portion of her opinion was joined only by two other justices, and in that portion Justice O'Connor wrote that "there must be the possibility of prompt judicial review in the event that [a] license is erroneously denied." 493 U.S. at 228 (opinion of O'Connor, J.). In the wake of this opinion, three federal circuit courts of appeal concluded that Justice O'Connor's language had altered one of the Freedman safeguards from prompt judicial resolution to mere prompt judicial review. See Graff v. City of Chicago, 9 F.3d 1309, 1324 (7th Cir. 1993) (en banc); TK's Video, Inc. v. Denton County, Texas, 24 F.3d 705, 707-08 (5th Cir. 1994); Boss Capital, Inc. v. Casselberry, 187 F.3d 1251, 1255-57 (11th Cir. 1999). Meanwhile, three circuit courts determined that prompt judicial resolution was still required. See 11126 Baltimore Blvd., Inc. v. Prince George's Co., Maryland, 58 F.3d 988, 992 (4th Cir. 1995) (en banc); Baby Tam \& Co., Inc. v. City of Las Vegas, 154 F.3d 1097, 110102 (9th Cir. 1998); Nightclubs, Inc. v. City of Paducah, 202 F.3d 884, 890 (6th Cir. 2000).

${ }^{42}$ See City of Littleton, Colo. v. Z.J. Gifts D-4, 541 U.S. 774, 781 (2004).

43534 U.S. 316 (2002). 
or manner of speech in a public forum. The Court reasoned that requiring protest groups-like other, non-expressive groups such as soccer players - to obtain a ministerial park permit did not pose dangers to speech because the regulation did not target speech content:

The Park District's ordinance does not authorize a licensor to pass judgment on the content of speech: None of the grounds for denying a permit has anything to do with what a speaker might say. Indeed, the ordinance (unlike the classic censorship scheme) is not even directed to communicative activity as such, but rather to all activity conducted in a public park. ${ }^{44}$

The Court was satisfied that the permit system, which was designed to prevent dangerous uses of municipal parks and to guarantee financial accountability in the event of damage to city facilities, was "not the kind of prepublication license deemed a denial of liberty since the time of John Milton but a ministerial, police routine for adjusting the rights of citizens so that the opportunity for effective freedom of speech may be preserved." 45

Two years later, in City of Littleton, Colorado v. Z.J. Gifts D-4,46 the Court took its predilection for content neutrality a step further in holding that the procedural safeguards of Freedman did not apply to a licensing regulatory scheme for adult businesses as long as that scheme was content neutral toward speech. The Court addressed Freedman's prompt judicial resolution requirement but did not discuss the other two procedural safeguards: placement of the burden of proof on the censor and maintenance of the status quo. ${ }^{47}$ Although the Court ostensibly concluded that a prompt judicial resolution and not mere judicial access was necessary, it nevertheless concluded that the regular judicial process already provided for relatively prompt resolution of First Amendment cases, like other cases. 48 The Court seemed unconcerned with any possible temporary restriction on speech primarily because the regulatory scheme was content neutral. ${ }^{49}$

\footnotetext{
${ }^{44} I d$. at 322

${ }^{45} \mathrm{Id}$. at 323.

46541 U.S. 774 (2004)

${ }^{47} I d$. at 782 .

${ }^{48} I d$. at 784 ("Colorado's rules provide for a flexible system of review in which judges can reach a decision promptly in the ordinary case, while using their judicial power to prevent significant harm to First Amendment interests where circumstances require.”).

${ }^{49} I d$. at 783 ("And the simple objective nature of the licensing criteria means that in the ordinary case, judicial review, too, should prove simple, hence expeditious. ... Where (as here and as in $F W / P B S$ ) the regulation simply conditions the operation of
} 


\section{Prior Restraint AND Content NeUtrality}

Scholars have recognized that content neutrality threatens to become the dominating principle of free speech jurisprudence. 50 The requirement of content neutrality stems from the idea that one of the major goals, if not the primary objective, of the First Amendment's speech and press clauses is to prevent the government from regulating speech based on its particular message. Advocates of this position contend that "equality is at the core of the First Amendment" and that " $[\mathrm{t}] \mathrm{o}$ allow the government to target particular views or subjects permits the government to greatly distort the marketplace of ideas." 51 This view, however, was not always the predominant interpretation of the meaning of the First Amendment. Early Supreme Court cases did not express concern with whether government regulation distinguished speech based on content, and it was not until the late 1930s that the Court even began to suggest that content-based regulation was likely to be more constitutionally suspect than content-neutral regulation. 52

Under the Supreme Court's body of case law applying the doctrine of content neutrality, content-based government regulation of speech is presumed invalid and is subjected to strict scrutiny. ${ }^{53}$ Strict scrutiny requires that the government demonstrate it has a

an adult business on compliance with neutral and nondiscretionary criteria ... and does not seek to censor content, an adult business is not entitled to an unusually speedy judicial decision of the Freedman type."). This sentiment was expressed by the Seventh U.S. Circuit Court of Appeals in 1993 when it questioned the need for Freedman's procedural safeguards and stated: "A person always has a judicial forum when his speech is allegedly infringed." Graff, 9 F.3d 1309, 1324 (7th Cir. 1993).

${ }^{50}$ See, e.g., Erwin Chemerinsky, Content Neutrality as a Central Problem of Freedom of Speech: Problems in the Supreme Court's Application, 74 So. CAL. L. REv. 49, 53 (2000) ("Today, virtually every free speech case turns on the application of the distinction between content-based and content-neutral laws."); Chris Demaske, Modern Power and the First Amendment: Reassessing Hate Speech, 9 CoMm. L. \& POL'Y 273, 274 (2004) ("Current free speech analysis is based in large part on content neutrality.”).

${ }^{51}$ Chemerinsky, supra note 50 , at 55-56.

${ }^{52}$ See Martin H. Redish, The Content Distinction in First Amendment Analysis, 34 STAN. L. REV. 113, 121 (1981). Redish recounts that, through the early years of the twentieth century, the Supreme Court "reserved much of its rhetoric about the values of free expression for cases invalidating content-neutral restrictions." Id. He contends that it was not until Cox v. Louisiana, 379 U.S. 536 (1965), that the Court turned away from concern for content-neutral regulations and began to emphasize the particular dangers of content-based regulations. Id. at 123.

${ }^{53}$ See Turner Broadcasting System, Inc. v. FCC, 512 U.S. 622, 642 (1994); R.A.V. v. City of St. Paul, 505 U.S. 377, 382 (1992). 
compelling interest in regulating speech and that its regulation be narrowly drawn to accomplish that purpose without affecting expression too broadly. 54 By contrast, the Supreme Court subjects content-neutral speech regulation only to an intermediate level of scrutiny "because in most cases [such regulation poses] a less substantial risk of excising certain ideas or viewpoints from the public dialogue."55 Intermediate scrutiny requires only that government regulation further a substantial government interest. The regulation must be narrowly drawn and leave open ample opportunity for the message to be communicated through alternative channels. 56 The relaxed nature of judicial review under intermediate scrutiny is embodied in United States $v$. O'Brien, 57 in which the Court upheld a regulation that prohibited draft-card burning. In O'Brien, the Court was largely unconcerned with the regulation's "incidental"-yet substantial-effect on speech. ${ }^{58}$

Even as the distinction between content-based and contentneutral regulation has become seemingly all-important, the exact definition of those concepts and even the basis for making such a distinction has remained somewhat murky. ${ }^{99}$ With respect to the basis for making the distinction, there are at least two possibilities: first, the intent or purpose of the government in propagating and enforcing the regulation; and, second, the impact of the regulation on expression. With respect to legislative intent, the Supreme Court has stated both that " $[\mathrm{t}]$ he government's purpose is the controlling consideration" 60 in determining whether regulation is content based and that "[i]llicit legislative intent is not the sine qua non of a viola-

${ }^{54}$ See Perry Educ. Ass'n v. Perry Local Educators' Ass'n, 460 U.S. 37, 45 (1983).

55Turner Broadcasting System, 512 U.S. at 642.

${ }^{56}$ See Clark v. Cmty. for Creative Non-Violence, 468 U.S. 288, 293 (1984).

57391 U.S. 367 (1968).

${ }^{58}$ Under $O$ 'Brien, the Court required that "the governmental interest [be] unrelated to the suppression of free expression; and [that] the incidental restriction on alleged First Amendment freedoms [be] no greater than is essential to the furtherance of that interest." 391 U.S. at 377.

${ }^{59}$ Scholarly discussion of this issue has noted that the distinction is difficult to draw. One scholar, for example, demonstrated how ostensibly content-neutral prior restraints can actually be content based when he established that some prior restraint schemes require private would-be speakers to show proof of insurance in case of damage to public property; insurance costs, however, are clearly applied in a content-based way, as it is common actuarial practice to charge more for insurance sought by unknown or distrusted groups because they pose a higher risk. See Eric Neisser, Charging for Free Speech: User Fees and Insurance in the Marketplace of Ideas, 74 GEO. L.J. 257, 308-37 (1985).

${ }^{60}$ Ward v. Rock Against Racism, 491 U.S. 781, 791 (1989). 
tion of the First Amendment." 61 Given confusion about whether legislative purpose is the key consideration behind content neutralitynot to mention the notorious difficulty of ascertaining the collective intent of a legislative body-it is not surprising that the definition of content-based regulation remains unclear. ${ }^{62}$

The Supreme Court itself acknowledged that "[d]eciding whether a particular regulation is content based or content neutral is not always a simple task."63 The Court has blithely stated that regulation is content based when the government adopts the regulation because of disagreement with the message conveyed 64 or because of hostility or favoritism toward a particular message. 65 On the other hand, the Court has said, regulation is content neutral when it "confer[s] benefits or impose[s] burdens on speech without reference to the ideas or views expressed."66 But it is not clear that the Supreme Court and other federal and state courts effectively recognize the difference between content-neutral and content-based regulation and make correct classification decisions. 67

Content neutrality has been criticized as being too narrow; among other proposals, scholars have suggested that an appropriate analytical framework would take into account not just whether the government targets a message for its content but also whether the speech is commercial or political (that is, the nature or character of speech) and whether the restriction is partial or total (that is, the scope of regulation), among other circumstantial factors. 68 Moreover, the Court has never convincingly explained why content-neutral regulation is less harmful to First Amendment interests than contentbased regulation. Theoretically, content-neutral regulation could abridge more speech than content-based regulation because, carried

\footnotetext{
${ }^{61}$ Simon \& Schuster, Inc. v. Members of the New York State Crime Victims Bd., 502 U.S. 105, 117 (1991) (internal quotation and citation omitted).

${ }^{62}$ For a close analysis of the definitional difficulties associated with the Supreme Court's distinction between content-based regulation and content-neutral regulation, see Clay Calvert, Free Speech and Content-Neutrality: Inconsistent Applications of an Increasingly Malleable Doctrine, 29 MCGEORGE L. REV. 69 (1997).

63Turner Broadcasting System, 512 U.S. 622, 642 (1994).

${ }^{64}$ Ward, 491 U.S. at 791.

${ }^{65}$ R.A.V., 505 U.S. 377, 386 (1992).

66Turner Broadcasting System, 512 U.S. at 643.

${ }^{67}$ See Calvert, supra note 62, at 71 (asserting that, sometimes, "laws and court orders that appear content based, either on their face or by their operation, are held content-neutral by the Supreme Court").

68See Demaske, supra note 50, at 280-82.
} 
to its extreme, content neutrality would allow suppression of all speech because then all speech would be treated equally. 69

As illustrated by the two cases previously discussed, Thomas and City of Littleton, the Supreme Court seems increasingly focused on content neutrality within the doctrine of prior restraint. Content neutrality, however, may be particularly ill-suited as the primary measuring stick for the constitutionality of government action that results in the prior restraint of speech. This is so for two reasons, one theoretical and one pragmatic. From a theoretical standpoint, allowing content-neutral prior restraint by the government does not square with what has been understood about the prior restraint doctrine for the last 225 years. From a pragmatic standpoint, the difficulties of defining content neutrality are exacerbated in the prior restraint context, thus threatening inhibition of even more speech than perhaps was intended by the Supreme Court when it announced Thomas and City of Littleton.

The doctrine of prior restraint encompasses two concepts. First, and most obviously, it stands for the idea that government may not prohibit communication or expression before the fact. At the time of the ratification of the First Amendment, freedom of speech and press in England and America meant that a printer could "put forth to the world what one wanted, as long as the printer was willing to accept the consequences of punishment for material considered illegal."70 This understanding is underscored by the wellknown assertion of Sir William Blackstone in 1769 that "liberty of the press ... consists in laying no previous restraints upon publications, and not in freedom from censure for criminal matter when published."71 Likewise, the Supreme Court early in the twentieth century adopted the rule that the First Amendment prevented "all such previous restraints upon publications as had been practiced

\footnotetext{
${ }^{69}$ See Redish, supra note 52, at 128-39. For a defense of the theoretical basis for the distinction between content-based and content-neutral regulation, see Geoffrey R. Stone, Content Regulation and the First Amendment, 25 WM. \& MARY L. REV. 189 (1983).

${ }^{70}$ Michael I. Meyerson, The Neglected History of the Prior Restraint Doctrine: Rediscovering the Link Between the First Amendment and the Separation of Powers, 34 IND. L. REV. 295, 311 (2001). See also Smith, supra note 23, at 450 ("A significant amount of historical evidence suggests that the first amendment was meant to preclude the possibility of future government-initiated actions aimed at stopping or punishing mere expression.").

${ }^{71} \mathrm{Id}$. at 311 (quoting William Blackstone, 4 COMmentaRIES 151-52 (Univ. of Chicago Press 1979) (1765-69)).
} 
by other governments." 72 The idea that certain prior restraintsnamely, those that are content neutral-are acceptable from a constitutional standpoint is, thus, difficult if not impossible to square with what the doctrine of prior restraint has meant for the nation's entire history.

The second concept encompassed by the doctrine of prior restraint deals with the constitutional principle of separation of powers. One scholar described the concept this way: "The 'prior' in the prior restraint doctrine refers not only to regulatory activity which is undertaken before the specific expression is communicated, but also when the executive or judicial branch acts out of its 'constitutional order' vis-à-vis the other branches of government." 73 Under this view, a prior restraint occurs whenever government suppresses expression before it has taken place, or whenever even a temporary prohibition of speech occurs without the benefit of a full and fair judicial hearing. ${ }^{74}$ This aspect of the prior restraint doctrine is primarily concerned with not allowing executive branch censors to make a final determination of whether speech may be constitutionally restrained before it is expressed. This is the concern addressed by the Supreme Court in Freedman when it articulated three procedural safeguards, particularly a requirement for a prompt judicial resolution.

In Professor Monaghan's view, at the heart of Freedman was the concept that the government could not deprive individuals and groups of their free speech liberty without ensuring due process. 75 Much of the due process guarantee came in the form of requiring that final censorship decisions be made by the branch of government most qualified to judge when speech interests should give way to legislative or executive regulatory interests:

Central to first amendment due process is the notion that a judicial, rather than an administrative, determination of the character of the speech is necessary. Cases in the obscenity area first established the principle, but neither their reasoning nor their language implies that the principle is restricted to obscenity determinations. ... Nothing in the rationale of Freedman and its predecessors suggests that their principles are confined to the obscenity area. In fact, when the subject

72Patterson v. Colorado, 205 U.S. 454, 462 (1907) (quoting Commonwealth v. Blanding, 20 Mass. 304, 313 (1825)).

${ }^{73}$ Meyerson, supra note 70 , at 339.

${ }^{74}$ See id. at 340; Redish, supra note 24 , at 75.

${ }^{75}$ Monaghan, supra note 4, at 518-19. 
matter of speech is political in character rather than bordering on the obscene, the need for a disinterested judicial judgment is even greater. One can, then, hypothesize as a general principle of first amendment due process that no procedure is valid which leaves the protected character of speech to the final determination of an administrative agency, no matter how "judicial" its procedure. ${ }^{76}$

Turning from theory to pragmatism, the idea that contentneutral prior restraints are presumptively constitutional may be unworkable. Distinguishing between content-based and contentneutral regulation is not an easy task with clear results even when speech already has taken place. When the determination must be made before the speech has been communicated, however, the task becomes even more difficult. The problem is that in the prior restraint context, it is unclear what effect a particular regulation has on speech and, therefore, the only alternative is to look to legislative intent for guidance. But as has been demonstrated, legislative intent is not always discernible and, even if it were, it would not be the sine qua non of deciding whether a particular regulation is constitutionally suspect. Thus, regulators, speakers and judges are left to guess about whether a regulation that has yet to be applied is content neutral with respect to a hypothetical form of expression.

\section{SAFeguards in The U.S. Courts of ApPeAL AfTer 2002}

A review of decisions from U.S. circuit courts demonstrates the extent to which the procedural safeguards of Freedman are disappearing from First Amendment jurisprudence. ${ }^{77}$ Of the seventeen federal intermediate appellate court opinions since 2002 citing either Thomas or City of Littleton, four cases arose in the context of local government licensing schemes for sexually oriented businesses. 78 The remaining opinions arose in various other contexts, including a licensing regime for leafleting and vending in down-

\footnotetext{
${ }^{76} I d$. at $520,524-25$.

77This study identified seventeen cases from federal circuit courts of appeal since 2002 citing the Supreme Court opinion in either Thomas or City of Littleton. Analysis of these intermediate federal appellate opinions forms the basis for the observations herein about the state of the Freedman safeguards in contemporary federal jurisprudence.

${ }^{78}$ See Deja Vu of Cincinnati LLC v. Union Twnshp. Bd. of Trustees, 411 F.3d 777 (6th Cir. 2005); Dream Palace v. County of Maricopa, 384 F.3d 990 (9th Cir. 2004); Encore Videos, Inc. v. City of San Antonio, 330 F.3d 288 (5th Cir. 2003); Fly Fish, Inc. v. City of Cocoa Beach, 337 F.3d 1301 (11th Cir. 2003).
} 
town Las Vegas, ${ }^{79}$ an ordinance requiring parade permits, ${ }^{80}$ a Department of Veterans Affairs' decision on flying the Confederate flag at a national cemetery in Maryland, ${ }^{81}$ a protest permit regime for the 2002 Winter Olympic Games in Salt Lake City, ${ }^{82}$ an Oregon highway billboard law, 83 the Oregon Mass Gathering Act, 84 a mass demonstration permit regime in Georgia, 85 a leafleting license regime for Boston's Fish Pier, 86 and sign ordinances in the Florida municipalities of St. Petersburg, ${ }^{87}$ Clearwater, 88 Neptune Beach 89 and St. John's County. 90 That fewer than one fourth of the recent cases arose in the adult business licensing context underscores Professor Monaghan's point that procedural safeguards and First Amendment due process are not confined to sexually oriented speech questions. ${ }^{91}$

The appellate judges who issued the seventeen opinions struggled somewhat to distinguish between content-neutral and content-based regulation. The Ninth Circuit Court, for example, concluded that there was no basis to determine whether the Las Vegas vending permit requirement was content neutral or content based because the regulation failed to set forth any standards to guide administrative decision making. ${ }^{92}$ Ultimately, the court held that the prohibition on vending without authorization was unconstitutional because it was susceptible to content-based application. ${ }^{93}$ Meanwhile, an absolute ban on leafletting in the public fo-

${ }^{79}$ ACLU v. City of Las Vegas, 333 F.3d 1092, 1095 (9th Cir. 2003).

${ }^{80}$ Reyes v. City of Lynchburg, 300 F.3d 449, 461 (4th Cir. 2002).

${ }^{81}$ Griffin v. Sec'y of Veterans Affairs, 288 F.3d 1309, 1315 (Fed. Cir. 2002).

${ }^{82}$ Utah Animal Rights Coalition v. Salt Lake City Corp., 371 F.3d 1248, 1250 (10th Cir. 2004).

${ }^{83}$ Lombardo v. Warner, 353 F.3d 774, 775-76 (9th Cir. 2003).

${ }^{84}$ S. Oregon Barter Fair v. Jackson County, 372 F.3d 1128, 1130-31 (9th Cir. 2004); S. Oregon Barter Fair v. Jackson County, 401 F.3d 1124, 1126 (9th Cir. 2005)

(Berzon, J., dissenting from denial of rehearing en banc).

${ }^{85}$ Burk v. Augusta-Richmond Co., 365 F.3d 1247, 1249-50 (11th Cir. 2004).

${ }^{86} \mathrm{New}$ England Regional Council of Carpenters v. Kinton, 284 F.3d 9, 15 (1st Cir. 2002).

${ }^{87}$ Granite State Outdoor Adver., Inc. v. City of St. Petersburg, 348 F.3d 1278, 1279-80 (11th Cir. 2003).

${ }^{88}$ Granite State Outdoor Adver., Inc. v. City of Clearwater, 351 F.3d 1112, 1115 (11th Cir. 2003).

${ }^{89}$ Solantic, LLC v. City of Neptune Beach, 410 F.3d 1250, 1252 (11th Cir. 2005)

${ }^{90}$ Cafe Erotica of Florida v. St. John's County, 360 F.3d 1274, 1278 (11th Cir. 2004)

${ }^{91}$ See Monaghan, supra note 4, at 519-25.

92ACLU v. City of Las Vegas, 333 F.3d 1092, 1107-08 (9th Cir. 2003).

${ }^{93} \mathrm{Id}$. 
rum was content neutral but unconstitutional because it was not narrowly tailored and did not leave open ample communication channels. ${ }^{94}$ Among the other sixteen federal circuit court opinions, five involved content-based regulation ${ }^{95}$ and eleven involved content-neutral regulation of speech. 96

Several of the federal appellate courts have concluded, in the wake of Thomas, that none of the three procedural safeguards are required when the licensing or permit scheme is content neutral. 97 The Eleventh Circuit, however, suggested in one opinion that at least one of the procedural safeguards might still be required for content-neutral regulation that could be applied in a content-based way. 98 The Fed-

${ }^{94} I d$. at 1106.

${ }^{95}$ See Solantic, LLC v. City of Neptune Beach, 410 F.3d 1250 (11th Cir. 2005) (sign ordinance was content based in that it exempted from the definition of a sign things such as flags and insignias, religious symbols, memorial signs, works of art and signs carried by a person, among others); Burk v. Augusta-Richmond Co., 365 F.3d 1247 (11th Cir. 2004) (county ordinance was content based because it required permits for groups of five or more demonstrators in a public forum and applied only to groups of protestors and not soccer players, sidewalk performers and tailgaters); Cafe Erotica of Florida v. St. John's County, 360 F.3d 1274 (11th Cir. 2004) (ordinance was content based because it limited the size of "political message" signs but not commercial signs); Fly Fish, Inc. v. City of Cocoa Beach, Fla., 337 F.3d 1301 (11th Cir. 2003) (concluding that an ordinance was content based because it banned nudity in adult entertainment establishments and not elsewhere in the city); Griffin v. Sec'y of Veterans Affairs, 288 F.3d 1309 (Fed. Cir. 2002) (military cemetery's flag display was content based because cemetery flew U.S. and POW/MIA flags but not Confederate flag).

${ }^{96}$ See Deja Vu of Cincinnati LLC v. Union Twnshp. Bd. of Trustees, 411 F.3d 777 (6th Cir. 2005) (en banc); S. Oregon Barter Fair v. Jackson County, 401 F.3d 1124 (9th Cir. 2005) (Berzon, J., dissenting from denial of rehearing en banc); Dream Palace v. County of Maricopa, 384 F.3d 990 (9th Cir. 2004); S. Oregon Barter Fair v. Jackson County, 372 F.3d 1128 (9th Cir. 2004); Utah Animal Rights Coalition v. Salt Lake City Corp., 371 F.3d 1248 (10th Cir. 2004); Encore Videos, Inc. v. City of San Antonio, 330 F.3d 288 (5th Cir. 2003); Granite State Outdoor Adver., Inc. v. City of St. Petersburg, 348 F.3d 1278 (11th Cir. 2003); Granite State Outdoor Adver., Inc. v. City of Clearwater, 351 F.3d 1112 (11th Cir. 2003); Lombardo v. Warner, 353 F.3d 774 (9th Cir. 2003); New England Regional Council of Carpenters v. Kinton, 284 F.3d 9 (1st Cir. 2002); Reyes v. City of Lynchburg, 300 F.3d 449 (4th Cir. 2002).

${ }^{97}$ See, e.g., S. Oregon Barter Fair, 372 F.3d 1128, 1137-38 (9th Cir. 2004) (regulation governing decision whether to grant permit for event billed as religious gathering, harvest celebration and counterculture craft fair); Utah Animal Rights Coalition, 371 F.3d 1248, 1259 (10th Cir. 2004) (regulation governing protests in Salt Lake City during 2002 Winter Olympic Games); Granite State, 348 F.3d 1278, 1281 (11th Cir. 2003) (municipal sign ordinance); Griffin, 288 F.3d 1309, 1328 (Fed. Cir. 2002) (regulation governing decision whether to allow placement of Confederate flag in national cemetery); New England Regional Council, 284 F.3d 9, 21 (1st Cir. 2002) (regulation governing permits for leafletting on sidewalks near Boston's Fish Pier).

${ }^{98}$ See Granite State, 351 F.3d at 1118 (stating that time limits on administrative decision making "are required when their lack could result in censorship of certain 
eral Circuit concluded that the procedural safeguards were not applicable to content-based government regulation of speech on government property classified as a nonpublic forum. ${ }^{99}$ In that case, the court acknowledged that, under Freedman and Thomas, the procedural safeguards normally apply when prior restraint is content based. 100 The court even expounded on the reasoning behind the procedural safeguards, specifically mentioning the danger of contentbased choices being made in the name of content-neutral regulation: "If a licensing scheme allows a government official to delay indefinitely before approving or denying a license, then a system masquerading as a time, place or manner regulation may in reality allow officials to suppress disfavored speech arbitrarily."101 Yet the court's refusal to apply the procedural safeguards made the statement somewhat of a self-fulfilling prophesy.

\section{Burden of Proof}

Although commentators and jurists characterized the Supreme Court's opinion in Freedman as speaking broadly and idealistically of requiring government censors to initiate legal action before deciding to censor speech, 102 and of imposing the burden of proof on the government once in court, the Freedman opinion itself stated only that "the burden of proving that the film is unprotected expression must rest on the censor."103 For this proposition, the Freedman Court relied on Speiser $v$. Randall, 104 in which the Court considered the constitutionality of a California property-tax exemption for military

viewpoints or ideas, ... but are not categorically required when the permitting scheme is content-neutral") (emphasis in original) (citing Freedman, 380 U.S. 51, 58-59 (1965) and Thomas, 534 U.S. 316, 322-24 (2002)).

${ }^{99}$ Griffin, 288 F.3d at 1328.

${ }^{100} I d$.

${ }^{101} I d$.

${ }^{102}$ In $F W / P B S$, Inc. v. City of Dallas, for example, Justice O'Connor wrote: "In Freedman, we determined that ... the censor must bear the burden of going to court to suppress the speech and must bear the burden of proof once in court." 493 U.S. 215, 227 (1990). Meanwhile, Professor Monaghan spoke broadly of the First Amendment due process established in Freedman and other cases. See Monaghan, supra note 4 , at $518-25$.

103380 U.S. 51, 58 (1965). Later in the opinion, the Freedman Court did state: "It is readily apparent that the Maryland procedural scheme does not satisfy these criteria. First, once the censor disapproves the film, the exhibitor must assume the burden of instituting judicial proceedings and of persuading the courts that the film is protected expression ... ." Id. at 59-60. The Court's comment about "instituting judicial proceedings," however, seems less critical in this passage than the requirement of "persuading the courts that the film is protected expression."

104357 U.S. 513 (1958). 
veterans that placed upon veterans the statutory burden to show that they were entitled to the exemption.

The California procedure in Speiser required veterans annually to apply for the veterans' property-tax exemption. 105 Part of the application form consisted of an oath of loyalty to the federal and state governments; the entire form, including the loyalty oath, was designed to facilitate the tax assessor's determination about whether the claimant was entitled to the exemption. 106 "The assessor [had] the duty of investigating the facts," the Court noted. "If the assessor believes that the claimant is not qualified in any respect, he may deny the exemption and require the claimant, on judicial review, to prove the incorrectness of the determination."107

The Court recognized that, generally, no constitutional violation would arise from a tax exemption scheme requiring the proponent of an exemption to establish his or her eligibility. 108 However, the Court said that such placement of the burden of proof was inappropriate when the tax liability turned out to be, in reality, punishment for a crime. ${ }^{109}$ In that case, the Due Process Clause of the Constitution required the burden of proof to be placed on the government; similarly, the Court held, due process required placement of the burden of proof on the government when it sought to deny a tax exemption because of disagreement with the proponent's speech. 110

The Court's suggestions in Freedman and subsequent cases that government must bear the burden of going to court and the burden of proof once there may be understood only against Speiser's discussion of due process. In reality, the burden safeguard was about ensuring that the government not be allowed to deprive speech proponents of their First Amendment liberties without due process. Thus, the core purpose of this procedural safeguard was that government must not be allowed to simply sit on a permit application advanced by a speech proponent. If the government were allowed to do that, the result would be effective deprivation of speech liberty without the opportunity to be heard on the appropriateness of such government prior restraint.

\footnotetext{
${ }^{105} \mathrm{Id}$. at 515 .

${ }^{106} I d$. at 517.

${ }^{107} I d$.

${ }^{108} I d$. at $524-25$.

${ }^{109} I d$. at 525 (citing Lipke v. Lederer, 259 U.S. 557 (1922)).

${ }^{110} \mathrm{Id}$. at 526 ("The man who knows that he must bring forth proof and persuade another of the lawfulness of his conduct necessarily must steer far wider of the unlawful zone than if the State must bear these burdens.").
} 
In Blount v. Rizzi, 111 for example, the Court emphasized that the Postmaster General's process for denying access to the mails was constitutionally deficient largely because postal officials could effectively censor speech by dragging their feet and simply refusing to make a decision one way or the other, all the while holding the postal materials in question. ${ }^{112}$ In that case, the Court held that "the fatal flaw of the procedure [was] failing to require that the Postmaster General seek to obtain a prompt judicial determination ...."113 Subsequently, the statutory scheme in Blount was characterized as one that was struck down in part because "an administrative order restricting use of the mails could become effective without judicial approval ...." 114

Unlike the other procedural safeguards, the burden safeguard was substantially undermined even long before the Supreme Court's 2002 opinion in Thomas. FW/PBS, Inc. v. City of Dallas, 115 in which the Supreme Court considered the constitutionality of Dallas' comprehensive sexually oriented business ordinance, has long been interpreted to stand for the idea that the burden safeguard was no longer required, at least in the adult business licensing context. 116 Many litigants no longer even bother to argue that a prior restraint scheme is unconstitutional for failing to place the burden of going to court, and the burden of proof once in court, on the administrative censor.117 The Ninth Circuit Court demonstrated the utter inapplicability of this procedural safeguard when it held that a prior restraint licensing scheme was not unconstitutional even though the speech proponent bore not only the burden to bring a legal challenge and the burden of proof once in court but

\footnotetext{
111400 U.S. 410 (1971).

${ }^{112} \mathrm{Id}$. at $417-18$.

${ }^{113} I d$. at 418.

114United States v. Thirty-Seven Photographs, 402 U.S. 363, 368 (1971).

115493 U.S. 215 (1990).

${ }^{116}$ See, e.g., Dream Palace v. County of Maricopa, 384 F.3d 990, 1001 n.6 (9th Cir. 2004) (relying on "Justice O'Connor's three-judge plurality opinion in $F W / P B S$ " as authority for eliminating the burden safeguard in the context of adult business licensing). In $F W / P B S$, Justice O'Connor-joined by Justices Stevens and Kennedywrote that the Dallas ordinance differed from the Maryland law in Freedman because it did not allow content-based choices by government censors and because there was greater incentive for adult businesses to litigate perceived constitutional violations. 493 U.S. at 229-30 (opinion of O'Connor, J.). For those reasons, Justice O'Connor wrote, there was no need to impose the burden of going to court and the burden of proof on the government. Id. (opinion of O'Connor, J.).

117See, e.g., Reyes v. City of Lynchburg, 300 F.3d 449, 455 (4th Cir. 2002) ("Also, no question is made in this case of any burden of proof required by the City to support the denial of a parade permit, the third Freedman requirement.").
} 
also the burden of proof in administrative proceedings. ${ }^{118}$ Some courts, however, still speak in terms of imposing the burden of proof on government when considering content-based regulation of speech subject to heightened scrutiny. 119

The loss of protection once afforded by this procedural safeguard might not in and of itself be overly harmful to First Amendment interests, if the other safeguards also remained in place. To some extent, this safeguard really addressed the same issue as the other safeguards-ensuring that administrative decision makers not turn a content-neutral licensing scheme into a content-based one by simply failing to make a decision about certain disfavored speech. That is the due process issue highlighted by Speiser. Without the burden of going to court being placed on the government, speech interests could still be served-and due process ensured-if administrative decision makers simply faced a time limit on their licensing decisions. But, as will be demonstrated, the idea that there must be a time limit on administrative decision making also has been undermined by federal court opinions since 2002 .

\section{Preserving Status Quo While Making Prompt Decisions}

In Freedman, the Supreme Court required that prior restraint licensing schemes ensure that the administrative censor will make a decision on whether to allow speech "within a specific brief period" and that, in the interim, the status quo must be preserved.120 Some courts recently have interpreted the status quo requirement to mean that speech should temporarily be allowed until a final decision is made. ${ }^{121}$ But in most cases, the status quo portion of this procedural safeguard is merely ignored in light of an ongoing inter-circuit (and intra-circuit) debate about the meaning of Freedman's "specified brief period" language.

Several circuits, including the Ninth and Tenth, have held that, after the Supreme Court's opinion in Thomas, content-neutral permit schemes are not required to impose any time limit on the administrative censor's decision. ${ }^{122}$ Although these courts cite Thomas as au-

\footnotetext{
${ }^{118}$ Dream Palace, 384 F.3d at 1002.

${ }^{119}$ See Burk v. Augusta-Richmond Co., 365 F.3d 1247, 1255 (11th Cir. 2004).

120380 U.S. 51, 59 (1965).

${ }^{121}$ See, e.g., Deja vu of Cincinnati LLC v. Union Twnshp. Bd. of Trustees, 411 F.3d 777, 788 (6th Cir. 2005).

${ }^{122}$ See, e.g., S. Oregon Barter Fair v. Jackson County, 372 F.3d 1128, 1138 (9th Cir. 2004); Utah Animal Rights Coalition v. Salt Lake City Corp., 371 F.3d 1248, 1259 (10th Cir. 2004).
} 
thority for the proposition, the permit scheme in Thomas imposed a twenty-eight-day limit on the administrative decision whether to grant a permit. ${ }^{123}$ In light of this fact, some federal circuit judges have argued that all prior restraint licensing schemes, including content-neutral ones, must have a time limit on the administrative decision. ${ }^{124}$ Seven active judges on the Ninth Circuit concluded that a Ninth Circuit panel's holding that a permit scheme need not contain any deadline for an official's decision "accord[ed] governmental authorities unbridled discretion, through official foot dragging, effectively to veto the holding of an event protected by the First Amendment." 125

The three-judge panel of the Ninth Circuit had considered the constitutionality of the Oregon Mass Gathering Act in light of a First Amendment challenge by the Southern Oregon Barter Fair, which applied for a permit in 1996 to hold an event described as a religious gathering, harvest celebration and counterculture crafts fair. ${ }^{126}$ The panel determined that the act was content neutral because it "applies to all mass gatherings irrespective of the purpose for the gathering [,] ... does not single out any particular activity or speech for regulation [, and] ... authorizes the Department of Human Services to promulgate regulations with respect to water supply, fire protection, and similar health and safety issues attendant on overnight gatherings of large crowds." 127 Thus, the panel concluded, the act was not required to include the Freedman procedural safeguards. ${ }^{128}$

But the court went a step further in holding that Thomas had concluded that content-neutral permit schemes did not need to provide a time limit on the administrative censor's decision about whether to grant a permit.129 The panel noted that, in Thomas, there was a twenty-eight-day deadline for the City of Chicago to make a decision

\footnotetext{
123534 U.S. 316, 322-23 (2002).

${ }^{124}$ See S. Oregon Barter Fair v. Jackson County, 401 F.3d 1124 (9th Cir. 2005) (Berzon, J., dissenting from denial of rehearing en banc). Under the Ninth Circuit Court's procedures, any active judge on the court may call for a vote on whether a case heard by a three-judge panel should be heard by an eleven-judge en banc panel. Such a call must receive support of a majority of the active judges on the court for the case to be reheard. The Ninth Circuit has twenty-eight active judges. See U.S. Court of Appeals for the Ninth Circuit, General Orders, ch. 5.5 (2005), available at http:// www.ca9.uscourts.gov/ca9/Documents.nsf/54DBE3FB372DCB6C88256CE50065FC B8/F769F3AD364D1B6D88256864007A1479?OpenDocument.

${ }^{125} \mathrm{Id}$. (Berzon, J., dissenting from denial of rehearing en banc).

${ }^{126}$ So. Oregon Barter Fair, 372 F.3d at 1130-31.

${ }^{127} I d$. at 1137.

${ }^{128} \mathrm{Id}$. at 1138 .

129Id. (citing Thomas, 534 U.S. 316, 322-23 (2002)).
} 
on permit applications; but, the panel said, the Supreme Court "did not indicate that the deadline was an essential component of a reasonable time, place, and manner regulation. To read the opinion that way would flatly contradict the decision's clear holding that time, place, and manner regulations need not contain the Freedman safeguards." 130 The panel ultimately concluded that even without the Freedman safeguards and time limit, the act did not confer unbridled discretion on government officials charged with making decisions about permits. 131

Under the Ninth Circuit's rehearing en banc procedures, however, a judge on the full court requested a vote on whether the panel's decision should be heard en banc. The vote ultimately failed, and the case was not reheard, but seven active Ninth Circuit judges dissented from the denial of rehearing en banc, largely based on disagreements with the panel's conclusion that Thomas had done away with the requirement of a time limit on a permit decision. 132 The dissenters attacked the panel's holding that a permit scheme need not contain any deadline for an official's decision. 133

Central to the dissenting judges' reasoning was a fine-line distinction some courts have not recognized among the outcomes of Thomas. The dissenting judges stated that Thomas included two holdings: first, that content-neutral permit schemes need not include the Freedman safeguards; and, second, that all permit schemes-including content-neutral ones-should "contain adequate standards to guide the official's decision and render it subject to effective judicial review,' so as to avoid their application 'in such a manner as to stifle free expression."'134 The panel, the dissenters said, ignored the fact that lack of a time limit on a permit decision effectively rendered the official decision without standards. 135 The dissenters speculated that perhaps the panel became confused because Thomas included discussion of whether the Freedman safeguards required prompt judicial review or a prompt judicial decision if a party

\footnotetext{
${ }^{130} I d$.

${ }^{131} \mathrm{Id}$.

${ }^{132}$ S. Oregon Barter Fair, 401 F.3d 1124, 1125 (9th Cir. 2005) (Berzon, J., dissenting from denial of rehearing en banc). See supra note 124.

${ }^{133} I d$. at 1124 ("The panel's decision is in square conflict with the very Supreme Court precedent upon which it relies, and will permit administrators to impede parties seeking to engage in First Amendment-protected activity on private property."). ${ }^{134}$ Id . at 1125 (quoting Thomas, 524 U.S. at 323) (Berzon, J., dissenting from denial of rehearing en banc).

${ }^{135} \mathrm{Id}$. (Berzon, J., dissenting from denial of rehearing en banc).
} 
was unsatisfied with a government official's permit decision. ${ }^{136}$ But, according to the dissenters, the issue of the speediness of judicial review was a separate question from the issue of a time limit on the administrative censor's initial decision about a permit. ${ }^{137}$

The Ninth Circuit case highlights the issue of whether the Freedman procedural safeguards were, after all, merely procedural. At least with respect to a time limit on the initial administrative decision, the safeguards seemed as much about substance as procedure. At their core, the safeguards aimed to ensure due process by requiring certain procedural formalities. This point is illustrated in several recent federal circuit cases reviewing prior restraint licensing schemes. For example, the New England Regional Council of Carpenters, a labor organization, challenged restrictions to its efforts to pass out leaflets on Boston's Fish Pier, owned by the Massachusetts Port Authority. ${ }^{138}$ In reviewing the permit scheme in question, the First Circuit noted that the prior restraint doctrine includes both substantive protections-primarily prohibiting unbridled discretion-and procedural protections, such as those embodied in Freedman's safeguards. ${ }^{139}$ The court concluded that the Fish Pier itself was a nonpublic forum, and, thus, the absolute prohibition on leafleting there need only be reasonable; the court found reasonableness due to the risk of obstructing vehicular traffic and distracting pedestrians. ${ }^{140}$

The court concluded that the sidewalks near the Fish Pier constituted a traditional public forum. Because the permit scheme focused on public safety issues, it was content neutral and, thus, under Thomas, the Freedman safeguards did not apply. ${ }^{141}$ The contribution made by the First Circuit was to clarify that what Thomas did was reduce the focus on procedure and increase the focus on substance when it comes to content-neutral permit schemes. In other words, those schemes don't have to meet certain procedures, but they should have some teeth-some standards to guide the administrative decision maker. Thus, the First Circuit said, Thomas reaffirms the line of cases beginning with Forsyth County $v$. Nationalist

\footnotetext{
${ }^{136} I d$. at 1127-28 (Berzon, J., dissenting from denial of rehearing en banc). That question was later decided by City of Littleton in favor of a prompt judicial decision. See City of Littleton, Colorado v. Z.J. Gifts D-4, 541 U.S. 774, 781 (2004).

137Id. at 1125-26 (Berzon, J., dissenting from denial of rehearing en banc).

${ }^{138}$ New England Reg'l Council of Carpenters v. Kinton, 284 F.3d 9 (1st Cir. 2002).

139 Id. at 21.

${ }^{140} I d$. at $24-25$.

${ }^{141} I d$. at 21.
} 
Movement 142 with respect to the substantive requirements for permit schemes. 143

But then the First Circuit subverted the value that might come out of substantive protections. The provision in question did not give much in the way of standards to guide the permit decision; essentially, permits could be revoked if leafleting posed "a danger to public safety or would impede the convenient passage of pedestrian or vehicular traffic." 144 But, in light of the fact that it found no evidence of "unfair or discriminatory" application of the public safety standard, the court deferred to the state's view that the permit scheme could be construed to limit discretion. 145 The court concluded: "If and when a pattern of abuse emerges, that will be the time to deal with infelicitous applications of the regulations." 146 The court also found it important that the permit scheme provided for automatic issuance of permits, which then had to be revoked if they posed safety hazard. 147

Meanwhile, two Eleventh Circuit opinions provide further basis on which to rest a conclusion that procedural and substantive protections are part of the same effort to protect speech interests and ensure due process. In reviewing the constitutionality of the St. Petersburg, Florida, sign ordinance, the court concluded that no time limits were required on a permit decision maker after Thomas. ${ }^{148}$ The court held that, even without a time limit, the content-neutral sign ordinance contained adequate standards to guide officials' decisions because signs could be rejected only for failure to meet objective criteria set forth in detail in the ordinance. 149 The court stated:

We realize City officials could potentially delay the processing of certain permit applications and thereby arbitrarily suppress disfavored speech. We will not, however, address hypothetical constitutional violations in the abstract. As the Supreme Court noted in Thomas, we believe "abuse must be dealt with if and when a pattern of unlawful favoritism appears, rather than by insisting upon a degree of rigidity that is found in few legal arrangements." 150

142505 U.S. 123 (1992).

143 Kinton, 284 F.3d at 21

${ }^{144} I d$. at $25-26$.

${ }^{145} \mathrm{Id}$. at 26.

${ }^{146} I d$.

${ }^{147} \mathrm{Id}$. at 25 .

${ }^{148}$ Granite State Outdoor Adver., Inc. v. City of St. Petersburg, 348 F.3d 1278 (11th Cir. 2003).

${ }^{149} \mathrm{Id}$. at 1282 .

150Id. (quoting Thomas, 534 U.S. 316, 325 (2002)). 
A different Eleventh Circuit panel put a slightly different spin on its interpretation of Thomas about a month after the case involving St. Petersburg, however. 151 Interpreting a similar sign ordinance in Clearwater, Florida, the panel seemed to back off from the statement that time limits on an administrative decision maker's permit decision might never be required; time limits, the court held, "are required when their lack could result in censorship of certain viewpoints or ideas, ... but are not categorically required when the permitting scheme is content-neutral." 152 Other courts have cited Thomas for the proposition that even though content-neutral permit schemes are not subject to Freedman safeguards, there must nevertheless be sufficient guidelines for a censor's decision or else a content-neutral scheme may be applied in a content-discriminatory way. 153

\section{Prompt Judicial Review}

As discussed previously, the Freedman requirement that a prior restraint scheme should "assure a prompt final judicial decision" 154 has become largely symbolic rather than effectual in contemporary licensing cases. In the years immediately following Freedman, lack of this procedural safeguard was invoked as justification for declaring prior restraints unconstitutional. As with the burden of proof safeguard, the heart of this safeguard seemed to be its focus on preventing administrative decision makers from dragging out decisions under a content-neutral scheme in such a way as to effectively restrict certain speech based on its content.

For example, in Southeastern Promotions v. Conrad, 155 the Court held that a municipality's decision not to allow presentation of the rock musical Hair in a city-leased theater infringed First Amendment rights because the city's procedure lacked the necessary safeguards. The Court pointed to lack of a prompt judicial review requirement, among other factors, and stated that "[e]ffective review on the merits was not obtained until more than five months" after the initial application. 156 The result of the application process

\footnotetext{
${ }^{151}$ Granite State Outdoor Adver., Inc. v. City of Clearwater, 351 F.3d 1112 (11th Cir. 2003).

${ }^{152}$ Id. at 1118 (emphasis in original) (citing Freedman, 380 U.S. 51, 58-59 (1965) and Thomas, 534 U.S. at 322-24).

${ }^{153}$ See ACLU v. City of Las Vegas, 333 F.3d 1092, 1107-08 (9th Cir. 2003); Reyes v. City of Lynchburg, 300 F.3d 449, 461 (4th Cir. 2002) (Michael, J., dissenting).

${ }^{154}$ Freedman, 380 U.S. at 59.

155420 U.S. 546 (1975).

${ }^{156} I d$. at 562 .
} 
was that the speech proponent was forced to delay production. ${ }^{157}$ Courts in other cases also expressed concern that the primary problem caused by lack of prompt judicial review was the risk of infringing timely due process and failing to provide substantive guidance to administrative decision making. ${ }^{158}$

In City of Littleton, the Supreme Court reaffirmed that adult business licensing schemes must ensure prompt judicial decision making rather than merely prompt access to judicial processes. ${ }^{159}$ However, that case also held that the judicial process as it already existed in Colorado was prompt enough to satisfy the Freedman safeguard.160 Thus, one of the three Freedman safeguards seemingly came to be meaningless, at least in the adult business licensing context.

Recent intermediate federal court opinions in which the permit scheme was content-based, necessitating the application of at least some of the Freedman safeguards, ${ }^{161}$ have dismissively pointed to City of Littleton in holding that normal judicial processes are sufficient to satisfy Freedman's prompt judicial review requirement. 162 For example, the Sixth Circuit recently concluded that an adult business licensing scheme in Ohio satisfied this requirement because the plaintiff "has given us 'no reason to doubt the willingness of [Ohio]'s judges to exercise the[ir] powers wisely so as to avoid serious threats of delayinduced First Amendment harm[.]"'163 Because of the limited applica-

\footnotetext{
${ }^{157} I d$.

158See, e.g., Vance v. Universal Amusement Co., 445 U.S. 308, 316 (1980) (stating that a Texas law "authorizes prior restraints of indefinite duration on the exhibition of motion pictures that have not been finally adjudicated to be obscene").

159541 U.S. 774, 780-81 (2004).

${ }^{160} \mathrm{Id}$. at 782 .

${ }^{161}$ As the Fifth Circuit noted in Encore Videos, Inc. v. City of San Antonio, 330
} F.3d 288, 296 (5th Cir. 2003), content-neutral regulation of sexually oriented businesses need only satisfy two of the Freedman requirements: maintaining the status quo and prompt judicial review. The placement of the burden of proof on the censor is no longer required after $F W / P B S$.

${ }^{162}$ See Bronco's Entm't Ltd. v. Charter Twnshp. of Van Buren, 421 F.3d 440, 447 (6th Cir. 2005) ("The ordinance does not establish special rules for an accelerated judicial decision, but such rules are unnecessary under Littleton... . Ordinary court rules are constitutionally sufficient ... ."); Odle v. Decatur Co., Tenn., 421 F.3d 386, 391 (6th Cir. 2005) ("Under the Supreme Court's recent decision in City of Littleton on what constitutes sufficiently prompt judicial review for purposes of a facial challenge to a licensing scheme, we conclude that the Act's provisions are more than adequate.”); Dream Palace v. County of Maricopa, 384 F.3d 990, 1003 (9th Cir. 2004) ("In effect, the Court in City of Littleton established a presumption that state courts function quickly enough, and with enough solicitude for the First Amendment rights of license applicants, to avoid the unconstitutional suppression of speech that arises from undue delay in judicial review.").

${ }^{163}$ Deja Vu of Cincinnati LLC v. Union Twnshp. Bd. of Trustees, 411 F.3d 777, 788 (6th Cir. 2005) (en banc) (quoting City of Littleton, 541 U.S. at 782). 
bility of the Freedman safeguards, it remains to be seen how courts will deal with the prompt judicial review issue in content-based prior restraint schemes other than the adult business licensing context.

\section{Observations About Content Neutrality and Prior Restraint}

After Thomas, most federal intermediate appellate courts have continued to hold to the idea that content-based prior restraint licensing schemes must still provide for the Freedman procedural safeguards in order to pass constitutional muster. ${ }^{164}$ But one of the results of Thomas may be to send the signal to lower courts that the procedural safeguards are no longer important. In at least one postThomas circuit court case, the procedural safeguards were not applied even though the prior restraint in question was clearly content based. In that case, a challenge was mounted to the Department of Veterans Affairs' decision not to fly the Confederate flag at a national cemetery in Maryland. 165 The decision was made pursuant to a federal regulation that prohibited unauthorized demonstrations, including flying of flags, on VA property. 166 The decision not to fly the Confederate flag was clearly content-based regulation, but the court held that the regulation was reasonable regulation of speech in a nonpublic forum. ${ }^{167}$ Although conceding that the federal regulation in question granted virtually unbridled discretion, 168 the court nevertheless concluded that the decision of which flag to fly was akin to government speech unrestrained by the First Amendment.169

\footnotetext{
${ }^{164}$ See, e.g., Solantic, LLC v. City of Neptune Beach, 410 F.3d 1250, 1271 (11th Cir. 2005) (holding that sign ordinance was content based-it exempted from definition of a sign things such as flags and insignias, religious symbols, memorial signs, works of art and signs carried by a person-and thus Freedman safeguards were required); Cafe Erotica of Florida v. St. John's County, 360 F.3d 1274, 1282 (11th Cir. 2004) (holding that sign ordinance was content-based-it limited the size of "political message" signs but not commercial signs-and applying Freedman safeguards); Burk v. Augusta-Richmond Co., 365 F.3d 1247, 1255 n.12 (11th Cir. 2004) (holding a county ordinance to be content based and observing that such an ordinance must satisfy Freedman's safeguards); Dream Palace v. County of Maricopa, 384 F.3d 990, 998, 1001 (9th Cir. 2004) (applying two Freedman safeguards to an adult business regulatory scheme); Fly Fish, Inc. v. City of Cocoa Beach, Fla., 337 F.3d 1301, 1313 (11th Cir. 2003) (holding that a licensing ordinance for adult businesses was unconstitutional in that it vested unbridled discretion in official decision makers in part because the ordinance failed to place a time limit on the officials' decision whether to issue a permit).

${ }^{165}$ Griffin v. Sec'y of Veterans Affairs, 288 F.3d 1309 (Fed. Cir. 2002).

${ }^{166} I d$. at 1319 .

${ }^{167}$ Id. at $1321-22$.

${ }^{168}$ Id. at 1323 .

${ }^{169} I d$. at $1324-25$.
} 
Another outcome of Thomas is the erosion of the arguably substantive time limit requirement on an administrative decision maker charged with deciding whether to allow speech. This poses the risk of failure to ensure due process, which was the primary concern behind procedural safeguards going back to Freedman and, before it, to Speiser. As previously discussed, the circuit courts that have considered the issue have determined that time limits are not required. But this may lead to the dubious principle that the earlier someone applies for a permit, the longer government can drag its feet. That this principle is more than mere speculation was demonstrated when the Utah Animal Rights Coalition applied in March 2001 to stage demonstrations during the 2002 Winter Olympic Games, scheduled for approximately one year hence in Salt Lake City. ${ }^{170}$ The city failed to respond for eight months and ultimately denied some of the coalition's requested times and places for demonstrations. The coalition challenged the ordinance, which required granting of permits unless the requested demonstrations conflicted with other events already planned, impeded traffic or conflicted with police and fire personnel movements. 171

The Tenth Circuit Court concluded that the ordinance was content neutral. 172 The court also held that Thomas, not Freedman, governed the challenge. The court then stated: "Under the guidance of Thomas, then, our inquiry narrows to whether the regulations: (1) possess adequate standards to guide the exercise of official discretion and make possible meaningful judicial review; and (2) are narrowly tailored to a significant state interest while leaving open satisfactory alternative means of communication."173 Although it was speaking in the context of a facial challenge to the Salt Lake City ordinance, the court reasoned that a limit on the decision maker's discretion was not necessary under the facts of the case because an eight-month delay did not hinder the coalition's plans to engage in speech during the Olympics, which were scheduled nearly twelve months after the filing of the initial permit application. ${ }^{174}$ Given that factual background, the court held that "there is no constitutional requirement for a fixed deadline in the context of permit applications under a content-neutral regulatory scheme."175 2004)

${ }^{170}$ Utah Animal Rights Coalition v. Salt Lake City Corp., 371 F.3d 1248 (10th Cir.

${ }^{171}$ Id . at $1251-52$.

${ }^{172} \mathrm{Id}$. at 1260 .

${ }^{173} \mathrm{Id}$.

${ }^{174}$ Id . at 1259.

${ }^{175}$ Id. at 1260 . 
Finally, the focus on content neutrality may be misplaced in some instances within the prior restraint context. This was illustrated when an Oregon homeowner with a large sign reading "For Peace in the Gulf" posted in his front yard brought a constitutional challenge to an Oregon highway billboard law. 176 The Ninth Circuit ultimately concluded that the content-neutral billboard law was constitutional because it did not place unbridled discretion in the hands of official decision makers, but a dissenting judge reasoned that content neutrality could not be determined without first examining the substantive standards governing the exercise of discretion: "Without 'narrow, objective, and definite standards to guide the licensing authority,' the [law]'s bare promise of content neutrality can never be tested." 177 Without definite standards, the statute could be applied in a content-based way and thus it would be impossible to say whether Freedman's safeguards should apply or not.

\section{CONCLUSION}

In Thomas and City of Littleton, the Supreme Court has partially discarded the procedural safeguards expounded four decades ago in Freedman. Essentially, the Court has replaced those procedural safeguards-maintenance of status quo during speedy administrative decision making, prompt judicial resolution, and placement of burden of proof on government censor-with the belief that content neutrality is enough to stem the tide of improper prior restraints of speech. But the procedural safeguards were more than proceduralthey stood for a broader understanding of the principle that the censors whose business it is to censor should not make final decisions about the propriety of their restraints of speech. The goal of ensuring due process as a means of protecting First Amendment speech interests may not be served by content neutrality in the absence of procedural safeguards.

It might be argued that loss of procedural safeguards after Thomas and, particularly, City of Littleton, is not particularly troubling to most speech because the safeguards primarily have been applied in the context of regulating adult businesses. In reality, however, the death of procedural safeguards in the content-neutral adult business licensing context is not the only potential speechimpairing result of current jurisprudence. More than three-quarters

\footnotetext{
${ }^{176}$ Lombardo v. Warner, 353 F.3d 774 (9th Cir. 2003).

${ }^{177} I d$. at 786 (B. Fletcher, J., dissenting) (quoting Forsyth County, 505 U.S. 123, $131(1992))$.
} 
of recent federal intermediate appellate opinions reviewed in this study did not deal with adult business licensing, and many of those opinions held that procedural safeguards were not necessary for prior restraint schemes targeting protest speech and other politically oriented speech. Just as Professor Monaghan concluded three decades ago that erection of a procedural safeguard did not protect speech only in obscenity cases, so too it is with contemporary erosion of those same safeguards. Loss of procedural safeguards in favor of content neutrality poses a risk to speech interests in multiple areas.

In light of Thomas and, to a lesser extent, City of Littleton, federal appellate courts have begun to further undermine the safeguards that were in reality both substantive as well as procedural. Without imposition of a time limit on administrative decision making regarding speech permits, the government may infringe speech without ever being forced to categorically reject a license application. In this sense, at least, recent intermediate appellate court opinions demonstrate that prior restraint jurisprudence is moving away from the idea that prior restraints are presumptively invalid and toward the idea that government may impede speech before it is communicated in all but the increasingly exceptional cases of content-based regulation. 